Fleay, C. \& Hartley, L. (2015) "II Feel Like a Beggar”: Asylum Seekers Living in the Australian Community Without the Right to Work', Journal of International Migration and Integration, DOI 10.1007/s12134-015-0453-x. (Final publication is available at link.springer.com).

\title{
'I Feel Like a Beggar': Asylum Seekers Living in the Australian Community Without the Right to Work
}

\section{Caroline Fleay and Lisa Hartley}

\begin{abstract}
While numbers of asylum seekers received by Australia are small compared to global figures, a range of deterrence measures have been implemented in response to increasing numbers arriving by boat in recent years. One of the more recent measures was denying asylum seekers who arrived by boat after 13 August 2012 the right to work upon their release from immigration detention into the community. There are around 26,000 asylum seekers who have been subject to this policy with most still waiting for their initial interview for refugee status and none have had their refugee claims resolved. This paper examines the findings of a study that explored the implications of this policy for asylum seekers. It draws on 29 semi-structured interviews with asylum seekers and highlights the distress and fear that many are enduring, caused by the denial of the right to work and ongoing uncertainty about their refugee claims. The study's findings provide support for the conclusions of earlier research that highlight the importance of the right to work and securing employment for the mental health of asylum seekers, as well as studies that found there were negative mental health consequences of forcing asylum seekers to live for long periods with uncertainty around their protection claims.
\end{abstract}

Keywords Asylum seekers, Right to work, Living in the community, Australia

\section{Introduction}

Many industrialised countries have introduced measures over the past few decades that are designed to deter the arrival of asylum seekers, including restricting the right to work. Perceptions that increasing numbers of asylum seekers are arriving to these countries help drive political pressures to adopt deterrent policies (Gammeltoft-Hansen 2014). This is despite it being the neighbouring countries to those that are the largest sources of asylum seekers that continue to host the vast majority of people fleeing persecution. The term asylum seeker refers here to a person who arrived to a country of asylum but whose refugee status is yet to be determined. According to the United Nations (UN) Convention Relating to the Status of Refugees (Refugee Convention), a person is found to be a refugee if it is considered likely they would face persecution in their home country due to their race, religion, nationality, membership of a particular social group or political opinion.

By the end of 2013, neighbouring countries to the largest source countries of asylum seekers hosted a total of 14.4 million or 86 per cent of the world's refugees according to the 
United Nations High Commissioner for Refugees (UNHCR) (2013a). Numbers of asylum seekers received by Australia continue to be very small in comparison. Although Australia received the largest number of asylum seekers by boat in 2012-2013 $(25,173)$ than in any previous year (Phillips and Spinks 2013), when compared with the number of asylum seekers worldwide in 2013 (UNHCR, 2013a), this was still just 2.1 per cent. In addition, figures provided by the Australian Department of Immigration and Border Protection (DIBP) on protection claims finalised over the past five years highlight that the vast majority of asylum seekers who arrived by boat have been found to be refugees. For example, 88 per cent of the refugee claims processed in 2012-13 for asylum seekers who came to Australia by boat resulted in protection visas being granted. During the previous three years, over 90 per cent of these claims resulted in protection visas being granted (DIBP 2013c).

Despite this, for more than twenty years Australia has adopted a range of deterrence measures in response to increasing numbers arriving by boat. One of the more recent measures is denying asylum seekers who arrived by boat after 13 August 2012 the right to work upon their release from immigration detention into the community. While a number of reports from non-government organisations outline concerns regarding the impacts of this measure (Gruhn 2014; UNHCR 2013b), no published research to date has explored the experiences of these asylum seekers. As at the end of January 2015, DIBP (2015: 3) reported that there were 26,168 asylum seekers living in the community who had been denied the right to work and provided with minimal financial support and access to services. While as at April 2015 some have since been provided with the right to work, thousands remain without this right. Most are also still waiting for their initial interview for refugee status and none have had their refugee claims resolved. This article explores the findings of research into the experiences of asylum seekers in this situation.

Earlier studies highlight the critical importance of the right to work and securing employment in restoring feelings of self-worth and improvements in mental health that deteriorate during long periods of seeking asylum and immigration detention (Da Lomba 2010; Fleay, Hartley and Kenny 2013). While the right to work is of profound importance to enable anyone to live a life with dignity, it 'is particularly important to refugees and asylum seekers as a means of survival' as well as a means of restoring a 'sense of dignity and selfworth' (Edwards 2005: 320). Having the right to work and securing employment enables asylum seekers to improve work and language skills, enhances their capacity for economic independence and fosters an ability 'to participate in and contribute to [a] host community' (Edwards 2005: 320). Other research highlights that granting the right to work to refugees and asylum seekers can benefit their host communities (Jacobsen, 2006). We build on this research by elevating the experiences of asylum seekers in the Australian context.

The findings of this research are based on in-depth interviews with 29 asylum seekers who were released from immigration detention in Australia into community-based arrangements with no right to work and limited entitlements. All of the men and women interviewed arrived to Australia by boat after 13 August 2012, the commencement date of this policy. The asylum seekers interviewed highlight that being denied the right to work and receiving only minimal financial support, and thus having long periods of time with very little to do, is both a source of and exacerbates feelings of great anxiety, sadness and fear. All of the interviewees expressed feelings and described experiences that suggest these policies are 
having a negative impact on mental health. After providing an overview of current Australian policy and research design and methodology, the key findings of this research are further explored in relation to the right to work and the findings of other studies.

\section{Overview of Current Australian Policies}

Along with many other industrialised countries over the past few decades, Australia has introduced measures that are designed to deter the arrival of asylum seekers, including denying the right to work to asylum seekers who arrive by boat. Most industrialised countries similarly place restrictions on asylum seekers' right to work. For example, asylum seekers in the UK are not permitted to work while their application is pending and can only apply after twelve months if their case has not been resolved and the delay is 'through no fault of the claimant' (Home Office, 2014). Germany allows asylum seekers to work after three months but they can only be considered for a job if no qualified Germans or foreigners with work permits apply (Stupp, 2014). In Norway and Denmark, asylum seekers can only access the labour market if they present a valid passport (Valenta \& Thorshaug, 2012) while in the Republic of Ireland asylum seekers are denied the right to work until they receive a decision on their application (House of Oireachtas, 2013). Likewise, the United States denies asylum seekers the right to work while they await the outcome of their refugee applications and are also prevented from receiving government welfare assistance (Human Rights Watch, 2013). A noteworthy exception to the trend towards restrictive work rights measures is Sweden, which allows asylum seekers the right to work immediately upon entry (Lundberg, 2013).

In November 2012 in Australia the former Labor Government first adopted the policy of denying the right to work to all asylum seekers who had arrived by boat since 13 August 2012 and were released from immigration detention centres. This was a response to the increasing number of boat arrivals that year compared with the previous year. It also followed the adoption of earlier policies in 2012 that attempted to deter the arrival of boats, such as sending asylum seekers who arrived after 13 August 2012 to regional processing centres on Nauru and Papua New Guinea's Manus Island.

As more asylum seekers continued to arrive to Australia by boat than could be sent to the regional processing centres, increasing numbers were held in Australian immigration detention centres. In November 2012 the Labor Government declared that all people who had arrived by boat since 13 August 2012 and who had not yet been sent to a regional processing centre could be released from Australian immigration detention centres on a communitybased arrangement with limited entitlements (Cullen 2012). This was consistent with the Labor Government policy that commenced in late 2011 allowing most asylum seekers to be released from detention prior to their protection claims being finalised. However, in contrast to those granted bridging visas under this previous policy, none of the asylum seekers released from detention who had arrived since 13 August were given the right to work.

The Labor Government's response to increased boat arrivals, which included an increase in arrivals from Sri Lanka, also involved the introduction of an "enhanced screening" process. Under this policy, boat arrivals from Sri Lanka have been subject to a screening interview by DIBP. If the Department considers that a person raises claims during this interview that potentially engage Australia's protection obligations, they are "screened in" 
and can make a protection claim. If not, they are "screened out" and removed from Australia (Australian Human Rights Commission 2013). It was reported in November 2013 that 3,072 asylum seekers from Sri Lanka were interviewed on this basis between 27 October 2012 and 31 October 2013, resulting in 1,056 being involuntarily returned and 159 voluntarily returned to Sri Lanka (Southern 2013). Serious concerns have been raised about this process as asylum seekers are interviewed without access to a lawyer and any determination that they are not entitled to Australia's protection is not subject to independent review (Kaldor Centre for International Refugee Law 2013).

In the wake of the election of the Coalition Government on 7 September 2013, the "screening out" process continued. The policy of denying the right to work to asylum seekers in the Australian community who arrived since 13 August 2012 also continued, in addition to further restrictions. As at the end of January 2015, there were 26, 168 asylum seekers in Australia who had arrived by boat and were living in community-based arrangements with no right to work and limited entitlements (DIBP 2015). The vast majority would have arrived since 13 August 2012. As at April 2015, many are living in the community without valid bridging visas given that DIBP had not been renewing those that had expired since at least the September 2013 election. It is still unclear when all of these visas will be renewed although recent reports have been made to the authors from some asylum seekers who have had their visas renewed. In order to get a renewed visa, however, asylum seekers are required to sign a "Code of Behaviour". This allows for the cancellation of their visa if criminal charges are laid against them, they are considered to engage in "antisocial" behaviour, or not cooperate with all "reasonable requests" from DIBP (Morrison 2013b). The Minister for Immigration and Border Protection also announced the Government's intention to implement a 'mutual obligation program to more effectively engage people who are on bridging visas' (Morrison 2013a). As at September 2014, it is unclear what this program will entail.

None of the asylum seekers who arrived since 13 August 2012 have had their refugee claims finalised and most have received no indication of when this may commence. Given the processing backlog faced by DIBP, it is likely that it will be up to three years before the claims of all asylum seekers living in the community will be finalised. Further, the Coalition Government had denied these asylum seekers access to funded migration agent support to prepare their protection applications and assist with review through the Immigration Advice and Application Assistance Scheme (IAAAS) (DIBP 2014a). While the Government announced in December 2014 that asylum seekers living in the community could now at least be granted the right to work by the Minister for Immigration and Border Protection while they wait for their claims to be processed (Yaxley, Norman and Gul, 2015), the process is administratively difficult and, as at April 2015, thousands continue to be without such a right. In addition, Federal Parliament passed legislation in December that significantly limits the capacity for independent review of claims decisions, introduces expedited claims processing, and only allows for temporary protection visas to be issued to those recognised as refugees (RCOA 2015). While these visas would include the right to work, they would not include the right to family reunion nor travel outside of Australia.

All of the 29 asylum seekers interviewed for this research project arrived to Australia by boat after 13 August 2012 and are subject to the policies outlined above. All were held in 
immigration detention centres in Australia until their release into the community upon being granted a Bridging Visa E (BVE) with no right to work and limited entitlements.

Bridging Visa E with No Right to Work

Most asylum seekers who arrived to Australia by boat since 13 August 2012 who have been released from immigration detention were issued a BVE. This temporary visa allows them to live in the community and remain lawfully in Australia while their refugee status is determined, but with a condition attached that denies them the right to work. They also receive minimal financial assistance, equivalent to 89 per cent of the national welfare payment for those in severe financial hardship - \$A222.95 per week for a single person. This is only 55 per cent of the amount calculated as the Henderson Poverty Line, which was \$A397.63 per week (including housing costs) in the June quarter 2013 (Melbourne Institute of Applied Economic and Social Research 2013).

In the first six weeks in the community, BVE holders who arrived after 13 August 2012, if referred by DIBP, are entitled to support funded by the Department. This includes the financial support outlined above and assistance to open a bank account, accommodation for up to 6 weeks (with an accommodation contribution payable to DIBP of \$A85 per week), assistance to find other accommodation, access to the national healthcare scheme and assistance to access physical and mental health care and pharmaceuticals approved by DIBP (Australian Red Cross 2013a). After the six-week transition period, unless a BVE holder is assessed as requiring additional assistance by DIBP, the support received is minimal (Australian Red Cross 2013b).

BVE holders are entitled to study but they must meet the required expenses themselves (Australian Red Cross 2013b). For those who are eligible to pursue studies at a technical college or university, this means they would need to pay international student fees. Children who hold BVEs are entitled to attend school. As at September 2014, all state Governments except for Western Australia admit children holding BVEs into their public education system (DIBP 2013b). BVE holders are also allowed to participate in volunteering activities. However, these are restricted to the activities offered by not-for-profit or local government agencies that have a volunteer program, no cash or in-kind benefits can be received, the activities must 'not otherwise be undertaken in return for wages by an Australian resident', and the volunteering should 'benefit the community' (DIBP 2013a).

English as a Second Language (ESL) classes offered under the resettlement program in Australia for permanent visa holders are not available for BVE holders. Instead they are entitled to access a six week abridged version of these classes, usually conducted for two to three hours, three days per week. Other English classes that can be accessed depend on where an asylum seeker may be living, their knowledge and capacity to participate in what is offered by service providers and community groups in that area, and the transport costs of getting to classes. Such courses are generally only conducted for short periods of time such as a few hours each week or several hours a day over three or four weeks. In summary, BVE holders have been living under the poverty line and face cost barriers and visa restrictions in accessing activities. 


\section{Research Design and Methodology}

This research involved interviews with 29 adults - 23 men and six women - who arrived to Australia by boat after 13 August 2012 and were living in the community on a BVE without the right to work after their release from immigration detention. The ratio of the numbers of men and women interviewed is comparable to the ratio of men and women who have come by boat to Australia seeking asylum over the past few years. For example, 85 per cent of boat arrivals recorded by DIBP as requesting Australia's protection in 2012-2013 were men (DIBP 2013c).

The semi-structured, in-depth interviews were conducted by the authors and interpreters were used when required. Each of the interviewees was first asked to describe the biggest challenges they faced living in the community on a BVE. Questions were then asked relating to activities they engaged in or wished to engage in, former employment, housing, health, claims processing, support networks, sense of belonging, and any other issues they identified as important. ${ }^{1}$

Face-to-face interviews were conducted with the participants during July-October 2013 in three major Australian cities. Ten participants were interviewed in Perth, all prior to the election of the Coalition Government on 7 September 2013. Nine participants were interviewed in Sydney and ten in Melbourne, all conducted after the election. Individual interviews were conducted with fifteen participants - thirteen men and two women. Four group interviews were conducted with men who were friends. Group interviews were also conducted with the adult members of each of two families and one interview was conducted with a married couple. Two families who participated were living in the community with their children, and one woman interviewed on her own was living in the community with her child. All of the interviewees were recruited through contacts known to the authors, such as former asylum seekers and advocates working with asylum seekers in the community.

Ten of the participants were from Afghanistan, all identifying as members of the Hazara ethnic group. Seven participants were from Sri Lanka, all identifying as Tamil. The remaining twelve were from Iran and identified with a number of different ethnic groups. The participants ranged from 18 to 65 years of age. 22 of the participants had employment and/or higher education experience prior to arriving in Australia. Former employment included in the fields of teaching, information technology, engineering, psychology, finance, sales, carpentry and plumbing. Some had commenced or completed studies in accounting, architecture, computer science, management, marketing and biology. The length of time that participants had been living in the community on BVEs without the right to work ranged from two weeks to 9.5 months. All of the participants have been given pseudonyms in this paper.

The interview transcripts were analysed using thematic analysis (Braun and Clarke 2006).

\footnotetext{
${ }^{1}$ These questions were based on the United Nations High Commissioner for Refugees (UNHCR) recommended basic reception standards for asylum seekers (UNHCR 2000).
} 
In our analysis, we used a deductive process meaning that themes were coded as they were identified in relation to interviewees' experiences of living in the Australian community, as opposed to using theory to guide our analysis. The transcripts and the related themes were managed with the assistance of NVivo 7, a qualitative software package.

\section{Findings: Living Without the Right to Work}

Not having the right to work was the over-riding concern expressed by those we interviewed. Living without the right to work and with minimal financial support was making it very difficult to fill each day with activities. Even though many we interviewed were trying to structure their days with some of the very few activities available and affordable to them, spending waking hours with very little to do served to compound the mental distress of their other concerns. This was particularly acute for those who had been living in the community the longest.

Living without the right to work: 'I worry too much...how am I meant to keep my mind busy?'

When those we interviewed were asked to identify the biggest challenges they faced now they were living in the community, not having the right to work was the most cited concern. This also generated the most discussion out of all the concerns raised in the interviews. In addition, some asylum seekers expressed concerns about not being able to study given the financial costs of doing so, and being denied the opportunity to participate in the English classes that are offered to refugees with permanent visas through the resettlement program. Access to short-term English classes depended on where the interviewees were living. In addition, while a number of interviewees spoke of a strong desire to undertake volunteer work to give them something to do with their time, only one person had managed to find such activities.

Many spoke of how long the days felt given they were not allowed to work or able to access studies. They described waking up as late as possible to minimise the time they would need to be awake during the daytime. The impact of spending long days with very little to do was linked to feelings of great anxiety, sadness and fear. As Ali in Sydney commented: 'I worry too much...how am I meant to keep my mind busy?' Sathiyan described the experience of not being able to work while waiting for his refugee claim to be assessed as profoundly traumatic.

In my country they truly actually torture people, kidnap and beat them up. But here in Australia they torture people mentally through the brain...We've been used as a sport or toy for political gain (Sathiyan, male, Sydney).

Mohammad spoke of his experience in Australia without the right to work or study as a continuation of the persecution he had experienced in his own country. 
Sometime we are just thinking that we are...some useless parts in the world. Just our people, Hazara people... Now Taliban has started special missions to kill the Hazaras...Even when we came to Australia so there is also no mercy to look after us (Mohammad, male, Sydney).

Some linked their anxiety and sadness around not being able to work with being denied a right that others in the community have.

The biggest challenge and the biggest worry is that whenever I wake up...I kind of feel like a lot of people around me, they have some of the rights, but I still don't have that right, and that is the work right...I've always felt miserable, right from the beginning, right from the time when I was born. Because in Afghanistan, even the people who are persecuting, they've always taken our rights, and even here, when I'm here, I don't really have the right to work and to just really enjoy whatever other people are doing, so that really, really worries me (Omed, male, Melbourne).

The importance of being able to work or study was associated with the importance of having a structure in daily life that would, in turn, mean that they would sleep better. Bahar, and many others, spoke of the difficulties they had in trying to sleep at night.

I was in Christmas Island [immigration detention centre], after that I have lots of nightmare. But I try to make myself very tired, exhausted when I go to sleep...I'm so disappointed about some things but I says whenever I get up in the morning I say that today is any other day and I thank God that today I'm healthy and I can breathe. I try to fight with life, you know (Bahar, female, Sydney).

In the absence of the right to work, most of those we interviewed were trying to cope by attempting to structure each day and week with some activities. Some were participating in free courses offered by local agencies or community groups, including short-term English classes, although they highlighted that such courses were usually too short to be effective. For those without families who they were trying to financially support as much as possible, some had found gyms with cheap membership deals to try to keep physically active. Others were visiting their local public library on a daily basis to read materials in their own language, attend any free classes, and to be around other community members.

Just normally, we just get up, come to the library, and we will pass the whole day at the library. We looked for some classes. If there were classes, then we'll go to classes. If not then we'll just go home - we'll just go back home (Hussain Ali, male, Melbourne).

Two of the interviewees were participating in a free community course on trade skills that was run two mornings each week over six months. A refugee advocate had discovered the course and facilitated their access. Rathan in Perth was the only one interviewed engaging in volunteer activities, helping for several hours each week with gardening as part of a community volunteer program. He described how important it was for him to at least be 'doing something' and interacting with members of the wider community. Omed talked about 
how he had tried to set up English classes for others in his situation until he realised the barriers to doing so.

I do want to deliver a free English class...but the thing was financially we were not in a very good state, as the printing, the advertising and stuff, we couldn't accomplish that, so that just fell apart... after a couple of weeks [we] realised that people were not feeling, like mentally they were not in a good status to come and attend the classes (Omed, male, Melbourne).

Having to spend every day without the opportunity to engage in work exacerbated the ongoing fear and uncertainty expressed by most of our interviewees regarding their refugee claims. Those interviewed after the September 2013 federal election expressed specific fears about the newly elected Coalition Government and Prime Minister Tony Abbott's negative comments about asylum seekers who arrived by boat. Some spoke of their deep fear that the Government may start forcibly returning asylum seekers to their home country. Naweed described what would be the dire consequences of returning people to his country.

If you're deported back to Afghanistan, you're going to be die over there...it's not humane (Naweed, male, Melbourne).

Each of the Tamil interviewees conveyed very specific fears about the Australian Government returning them to Sri Lanka. Many spoke of knowing individuals subjected to the "enhanced screening" process who had been "screened out" and subsequently returned to Sri Lanka. Some recounted stories of people they knew who had been arbitrarily detained or tortured upon their return. These accounts had made them particularly distrustful of the Government.

I don't know if I can trust [the Government] anymore because of the people being sent back [to Sri Lanka], being tortured on based on what they said here (Kumar, male, Sydney).

Some of the Tamil interviewees highlighted concerns about being sent to one of the regional processing centres. Others described how the lack of certainty about their future and fear of being forcibly removed from Australia had left them feeling extremely unsafe and vulnerable.

In case immigration want to deport me or deport us we are happy to write a note to them telling I give permission to inject me with poison so I could die when I arrive in Sri Lanka, that's how we feel about deportation (Sathiyan, male, Sydney).

Another issue raised was that some asylum seekers' bridging visas were close to expiration or had expired, which made many of the interviewees feel even more vulnerable. Suresh described how his daily thoughts were pre-occupied with worrying about whether he and others would be granted another bridging visa and, if not, whether they may be forcibly returned. 
Because our visas are expiring, we don't know what's going to happen and we can't really concentrate on anything else, we just think about visa is going to expire, what's going to happen to us next. That's taking all our energy and time (Suresh, male, Perth).

Interviewees also expressed concerns about the lack of clarity regarding the refugee claim process, and whether they would eventually be granted protection. Only two of the 29 asylum seekers we interviewed had been contacted by DIBP regarding their refugee claim. They had received assistance from a migration agent to prepare their statements before the election of the Coalition Government. None of the other interviewees had received any contact from DIBP about when their claims process may commence.

These comments suggest these asylum seekers are experiencing high levels of distress given the combination of being denied the right to work, uncertainty over their refugee claim and visa status, and the fear of being removed from Australia. While their pre-migration experiences are not known, it is possible they were exposed to trauma prior to their journeys to Australia. Particularly in regards to the Sri Lankan interviewees, Silove and Steel's (1998) study may be illustrative of the extent of this mental distress, and how the impacts of trauma prior to migration are exacerbated by the denial of the right to work and fear of being removed. Their study found that Sri Lankan asylum seekers living in the community in Australia with 'high levels of pre-migration trauma exposure showed greater posttraumatic stress reactions than other asylum seekers' when they were denied the right to work or unemployed, and experienced 'fears of being sent home' (1998: 17). Other studies have also associated fears of being forced to return to country of origin with negative mental health impacts (Johnston 2009; Milosevic et al. 2012; Steel et al. 2006). Similarly, Spike et al. (2011) and Steel et al. (2011) concluded that security, safety and certainty are important factors for the mental health and wellbeing of asylum seekers.

Another concern raised by many interviewees was their intense worry for the safety and wellbeing of their families and loved ones living in dangerous situations overseas and in regional processing centres, and about when, or if, they would be able to bring them to safety. Hussain Ali expressed fears about his family that he left behind in an effort to claim asylum for them all.

Back in [Quetta], my family does not have anybody there...they are without any work. They are there without any dependent...I'm the only person supporting my family...I was scared of the Taliban so I left my family there (Hussain Ali, male, Melbourne).

The mental health consequences for asylum seekers who continue to have such fears are also suggested in other studies. Johnston (2009) and Milosevic et al. (2012) associated fears for the safety of loved ones in dangerous situations with negative mental health impacts, further indicating the extent of the distress of the interviewees with families in such conditions in our research.

Despite the efforts of many we interviewed to cope with long days without being able to work or study, the mental distress of their situation and multiple concerns was clearly evident. Aliyah, living in Melbourne with her small child, described 'hopelessness' as 'the 
only feeling' she had. Many others expressed similar feelings of hopelessness as well as loneliness and powerlessness.

Because we are lonely and we don't have anyone to share our thoughts or what we're going through, especially the people who are surrounded with me or around me having the same problem or similar problem, and because things not solving back in the country as well and if I hear something that...will upset me or will that put more pressure on me and then sometime I even think about suicide and things (Raja, male, Sydney).

While it cannot be ascertained from this study if there is a length of time beyond which living in this situation becomes harmful for mental health, the feelings expressed by interviewees who had been in the community the longest were particularly acute. Mohammad Zaman in Melbourne had been living in Australia in this situation for 9.5 months and was visibly distraught about living without the right to work and with ongoing uncertainty for so long.

The challenges that I have struggled in my life I can't even speak about it. It has been so hard on me. The happiness and the joy that we had when we first landed on Christmas Island, that's fading now. That's fading, it's not the same joy and happiness that we had. Being in limbo is a huge concern for us (Mohammad Zaman, male, Melbourne).

Similarly, Naweed had been living in the community on a BVE for more than eight months and feared for his mental health should his situation not change.

There is no brightness for the future and, you know, after three years, after four years when I be like that here, everything will be removed from my mind (Naweed, male, Melbourne).

These findings reinforce the conclusions of other research on the experiences of asylum seekers and refugees and policies in relation to employment and mental health. For example, Taylor (2000) explored the implications of the Howard Coalition Government denying the right to work to 60 per cent of asylum seekers living in the Australian community in the late 1990s, many of who were not entitled to receive government funded financial assistance. Based on interviews with refugee support agency employees, her findings highlight the mental as well as physical health impact of living in such a state of uncertainty and poverty. Not surprisingly, the physical and mental health of asylum seekers, in many cases undermined already by their home country experiences, tends to deteriorate markedly over the period of time they spend in the community waiting for their protection visa applications to be determined (Taylor 2000).

McNevin and Correa-Velez (2006) raised similar concerns in relation to the mental health of asylum seekers living in the community on BVEs without the right to work and with no government financial assistance. Through interviews with staff members of agencies providing support services to asylum seekers, the study concluded that 'BVE conditions appear to be exacerbating pre-existing medical conditions and generating new ones. This is particularly the case in terms of mental health' (McNevin and Correa-Velez 2006: 131). 
Studies in the UK with asylum seekers have demonstrated similar findings, including that denying the right to work has 'negative impacts on feelings of self-worth and the ability to integrate into society' (Doyle 2009: 5). Long periods of being forced to do very little while waiting for refugee claims to be finalised, due to the denial of work rights and no access to government supports, was seen as 'creating unnecessary dependency [on support networks], and reducing confidence' (Wren 2007: 407).

While the group of asylum seekers interviewed for our research are at least able to access minimal government funded financial assistance, they described experiences and feelings indicating a decline in mental health while they continued to wait for their refugee claims to be processed. This suggests that providing minimal financial assistance that is significantly below the poverty line does not address the mental health implications of living without the right to work and with uncertainty over long periods of time. An important factor in this is '[h]aving too much time to introspect', found to be a significant source of stress for people from a refugee background in a refugee resettlement study in Australia (Sulaiman-Hill and Thompson 2012: 132). The minimal amount of financial assistance received means that it is also very difficult to meet living costs, in addition to the demeaning experience of having to rely on such assistance.

Living with minimal financial support: 'I feel like a beggar'

Many of those we interviewed talked about how difficult it was to survive without having the right to work and receiving a minimal fortnightly payment from the government. Interviewees spoke about the problems they faced meeting the costs of rent, household bills, food and phone cards with the minimal financial assistance received.

Finding affordable accommodation and meeting rental payments was the most significant financial concern for those we interviewed. Mina commented that for herself and her husband,

the money that we get it's not enough to buy food and pay for the rent. So we had to get just one room and 10 people are living in this flat, this house (Mina, female, Perth).

A number of interviewees described how they had stayed temporarily in friends' houses on couches and on the floor while they were trying to source more stable accommodation. Riaz had slept for a week in a car.

[My brother said] I can't find you any place so I lend my car then you can sleep in my car (Riaz, male, Perth).

Some of the interviewees described living in very poor conditions, including Aimad and Pooran. They found living with their three children in sub-standard conditions to be humiliating. When they had first moved to this house, it was without electricity and heating in the Melbourne winter and it was only through the intervention of a refugee advocate that they secured beds and heating. They also expressed their concerns about not being able to afford what their children may need at school and the humiliation this may cause. 
The problem is the children with them there [at school], [they] won't understand how the other parents are living. So they will ask them: why didn't you buy this? (Pooran, female, Melbourne)

The two other families with children interviewed had only accessed adequate housing and essential items such as bedding through the assistance of refugee advocates. Aliyah, living in Melbourne with her small child without family support, was without access to childcare and thus had an additional barrier to being able to access activities outside the home.

All interviewees particularly mentioned how they often could not afford to go anywhere other than by walking given the costs of public transport. This included those living in the state of Victoria where BVE holders can access concession fares. Public transport costs added a further barrier to accessing activities and services for those we interviewed, and often meant that they would stay at home, socially isolated from the broader community.

Most of the time it's like we are in a cage (Criss, male, Melbourne).

Others stressed that not being able to work and help financially support family members in their home country was adding to their anguish.

It's a big struggle...we only came here to seek safety. I didn't come here [because of] work, but when our families not looking after themselves or having three meals, that also upset us that we be in a situation that we can't help them as well (Raja, male, Sydney).

Having the right to work was also linked to being able to contribute to the Australian society and economy. Ali was acutely worried about how Australians perceived him and other asylum seekers given they were not working.

I think the Australians think I am lazy, the refugees are lazy. We are not. We are not allowed to work (Ali, male, Sydney).

Many of those we interviewed spoke of a desire to contribute to Australia, as did almost all 81 participants of Sulaiman-Hill and Thompson's (2012) study of resettled refugees in Australia and New Zealand. Some in our study said that this opportunity was necessary in order to feel they belong in Australia. Others expressed this in terms of the importance of being independent and not reliant on scarce government funding.

Because we're not working we don't pay taxes, we feel that we are not - we don't belong here because we can't contribute to this country. When we work and when we pay our taxes then we feel we are a member but for the time being we think that we can't be a part and we always think that we are a burden for Australia (Mina, female, Perth).

Some expressed that being forced to rely on government financial support was a demeaning existence. 
I feel like kind of cheap when getting money, I feel like a beggar. But what I understand is if I had the right to work, I could work, and this money that they were giving to us, they could just spend that on a lot of other areas which is necessary and vital (Omed, male, Melbourne).

In contrast to the demeaning experience of being forced to rely on government support, securing employment can lead to feelings of independence and be a 'significant source of empowerment' (Da Lomba 2010: 424). Being granted the right to work and gaining employment was found to be important in restoring the mental wellbeing of asylum seekers and refugees who had endured long periods of immigration detention in Australia in 20102012. Eleven men were interviewed after their release into the community following 15-25 months in detention and those who had been given the right to work and secured employment expressed the positive impact this had on their feelings of self-worth (Fleay et al. 2013). Employment can also help to redress the social isolation that asylum seekers experience when there is no access to work or study. As found by Da Lomba (2010), a lack of access to work and study can inhibit the capacity of asylum seekers to develop social connections with the broader community.

While having the right to work cannot address fears expressed by the interviewees of this study for the safety of their loved ones and ongoing delays and uncertainties around their protection claims, it could be a potential coping mechanism. Securing employment could play an important role in coping with the ongoing fears and uncertainties that asylum seekers in the Australian community are enduring. The potential impacts of employment on self-worth and their ability to financially support families may at least contribute to the capacities of asylum seekers to live with these other sources of great distress.

As Kumar highlighted in his interview, allowing asylum seekers to work could also result in Australia benefiting from their employment skills and experience.

There's a lot of skilled or educated people there. The people - the government - should make use of that... Because the government not making use of them, their skills are being destroyed (Kumar, male, Sydney).

Most of our interviewees had employment and/or higher education experience prior to arriving in Australia and all expressed their strong desire to commence work, if not in their own field then in any employment.

Granting the right to work not only provides asylum seekers with the opportunity to support themselves and their families, but also for job-related skills to be maintained and enhanced. Asylum seekers interviewed for this research were concerned that their skills would fade due to being denied the right to work. Their concerns are supported by research that found such de-skilling to be a major factor leading to unemployment for refugees upon exile (Hugo 2011). Other research highlights the benefits that the economies of host communities could gain from the skills of many asylum seekers (Phillimore and Goodson 2006). This indicates that granting the right to work could enable asylum seekers to not only be financially independent, but to maintain and develop their job-related skills that could potentially contribute to the Australian economy. 
While those interviewed for our research clearly identified the importance of the right to work being granted, there are non-legal barriers to securing employment that would need to be addressed for asylum seekers to realise any such right. Fleay et al. (2013) highlight the importance of addressing such barriers and conclude that formal support mechanisms need to be provided by appropriate agencies to help facilitate access to employment (see also Croucher 2007). The temporary status of a bridging visa could be another barrier should the right to work be granted. As Marston (2004) found in relation to refugees in Australia who were granted temporary protection visas under the Howard Coalition Government, temporary visas can dissuade employers from hiring people who only have documents suggesting they will be in Australia in the short term. Temporary visas may also allow for discriminatory attitudes and practices by employers (Marston 2004). In addition, limited English language skills can be a significant barrier to employment (Da Lomba 2010; Marston 2004; Phillimore and Goodson 2006; Waxman 2001). This highlights the importance of providing appropriate English language tuition to asylum seekers in the community, as well as other pathways for study to further enable access to employment. Granting the right to work is not enough gaining employment needs to be enabled.

\section{Conclusion}

The asylum seekers interviewed highlight that living without the right to work and receiving minimal financial support, and subsequently spending long periods of time with very little to do, is both a source of and exacerbates feelings of great anxiety, sadness and fear. The Australian Government's denial of the right to work to asylum seekers who arrived after 13 August 2012, and ongoing delay in assessing their refugee claims, is having a distressing impact on these asylum seekers. Descriptions provided by some of the interviewees of their experiences included that these policy impacts were a form of mental torture and persecution. The feelings expressed and experiences described by all of the interviewees suggest these policies are having a negative impact on mental health.

While the number of interviewees limits the degree to which these findings can be generalised to the wider population of asylum seekers in Australia, this study strongly suggests that Australian policy is having a negative mental health impact on at least some asylum seekers. This is reinforced by similar concerns raised by non-government organisations' reports about this group of asylum seekers (Gruhn 2014; UNHCR 2013b). It is further supported by the conclusions of earlier studies outlined above that highlight the importance of the right to work and securing employment for the mental health of asylum seekers, as well as studies that found there were negative mental health consequences of forcing asylum seekers to live for long periods with uncertainty around their protection claims. Consequently, the Australian Government should grant the right to work and enable access to education for all asylum seekers living in the community upon their release from immigration detention. While the Minister for Immigration and Border Protection's announcement in December 2014 that asylum seekers could now be granted the right to work while they wait for their claims to be processed (Yaxley, Norman and Gul, 2015) is welcome, the process is administratively difficult and, as at April 2015, thousands continue to be 
without such a right. The process needs to be expedited and asylum seekers who are unable to cope with finding and maintaining employment should be provided with access to the national welfare payment. In addition, further research is needed to explore the impacts of granting the right to work to asylum seekers in Australia and other countries. Very few countries grant the right to work to asylum seekers and the experiences of those who have had this right, as well as the economic contributions this makes to local communities, have been greatly overlooked.

\section{Acknowledgements}

We would like to acknowledge the men and women interviewed for this research and thank them for their willingness to share their experiences with us. This research was funded by the Australia-Asia-Pacific Institute and the Centre for Sport and Recreation Research at Curtin University, and a Curtin Humanities Publication Grant.

\section{References}

Australian Human Rights Commission. (2013). Tell me about: the "enhanced screening process. http://www.humanrights.gov.au/sites/default/files/document/publication/enhancedscreening.pdf Accessed 29 September 2014.

Australian Red Cross. (2013a). Community Assistance Support Program. http://www.redcross.org.au/community-assistance-support.aspx. Accessed 1 February 2014.

Australian Red Cross. (2013b). Asylum Seeker Assistance Scheme. http://www.redcross.org.au/asylum-seeker-assistance-scheme.aspx. Accessed 1 February 2014.

Braun, V. \& Clarke, V. (2006). Using thematic analysis in psychology. Qualitative Research in Psychology, 3, 77-101.

Croucher, G. (2007). A chance to contribute: Some remarks on the potential economic impact of allowing asylum seekers the right to work. Just Policy, 44, 37-43.

Cullen, S. (2012). First asylum seekers arrive on Manus Island. ABC News, 21 November. http://www.abc.net.au/news/2012-11-21/first-asylum-seekers-arrive-on-manusisland/4383876. Accessed 30 August 2014.

Da Lomba, S. (2010). Legal status and refugee integration: A UK perspective. Journal of Refugee Studies, 23(4), 415-436.

DIBP. (2013a). Summary of what Asylum Seekers Arriving by Boat Without a Visa May Access under Community Support Programs. August. 
DIBP. (2013b). Community Programmes Service Providers’ Newsletter \#8 November.

DIBP. (2013c). Asylum Trends: 2012-2013. November. http://ww.immi.gov.au/media/publications/statistics/immigration-update/asylum-trends-aus2012-13.pdf. Accessed 24 August 2014.

DIBP. (2014a). Removal of the Immigration Advice and Application Assistance Scheme and introduction of Protection Application Information and Guides. March. http://www.immi.gov.au/Live/Documents/paig-g.pdf. Accessed 24 August 2014.

DIBP. (2014b). Illegal Maritime Arrivals on Bridging E Visa. 30 June. http://www.immi.gov.au/pub-res/Documents/statistics/ima-bve-30-june-14.pdf. Accessed 2 February 2015.

DIBP. (2015). Immigration Detention and Community Statistics Summary 31 January 2015. http://www.immi.gov.au/About/Documents/detention/immigration-detention-statisticsjan2015.pdf. Accessed 12 February 2015.

Doyle, L. (2009). "I hate being idle". Wasted skills and enforced dependence among Zimbabwean asylum seekers in the UK. http://www.refugeecouncil.org.uk/assets/0001/7049/I hate being idle.pdf. Accessed 24 August 2014.

Edwards, A. (2005). Human rights, refugees, and the right "to enjoy" asylum. International Journal of Refugee Law, 17, 293-330.

Fleay, C., Hartley, L. \& Kenny, M.A. (2013). Refugees and asylum seekers living in the Australian community: The importance of work rights and employment support. Australian Journal of Social Issues, 48(4), 473-93.

Gammeltoft-Hansen, T. (2014). International Refugee Law and Refugee Policy: The Case of Deterrence Policies. Journal of Refugee Studies, doi:10.1093/jrs/feu030.

Grugh, R. (2014). “Can you please help me? How can we live?” UnitingCare's emergency relief and crisis support for asylum seekers living in the community. March. http://apo.org.au/research/can-you-please-help-me-how-can-we-live-unitingcares-emergencyrelief-and-crisis-support. Accessed 2 September 2014.

High Court of Justice. (2014). Detention Action v Secretary of State for the Home Department. Case No: CO/6966/2013. In the High Court of Justice, Queen's Bench Division, Administrative Court, 9 July. http://detentionaction.org.uk/wordpress/wpcontent/uploads/2014/07/Detention-Action-DFT-FullJudgement.pdf?utm_source $=$ Weekly + Legal + Update\&utm_campaign=ea2ebbf6ba- 
WLU_11_07_2014\&utm_medium =email\&utm_term $=0 \_7176 \mathrm{f0fc} 3 \mathrm{~d}-\mathrm{ea} 2 \mathrm{ebbf6ba}-420559425$. Accessed 2 September 2014.

Hugo, G. (2011). A Significant Contribution: Economic, Social and Civic Contributions of First and Second Generation Humanitarian Entrants. http://www.immi.gov.au/media/publications/research/_pdf/economic-social-civiccontributions-booklet2011.pdf. Accessed 12 August 2014.

House of Oireachtas (2013). Written answers Nos. 472-490: Asylum applications. http://oireachtasdebates.oireachtas.ie/debates\%20authoring/debateswebpack.nsf/takes/dail201 3062500091?opendocument\#WRX01250. Accessed 17 May 2015

Home Office (2014). Asylum policy instruction: Permission to work. https:/www.gov.uk/government/uploads/system/uploads/attachment_data/file/299415/Permis sion_to_Work_Asy_v6_0.pdf. Accessed 15 May 2015.

Human Rights Watch (2013). At least let them work: The denial of work authorization and assistance for asylum seekers in the United States.

http://www.hrw.org/reports/2013/11/12/least-let-them-work. Accessed 15 May 2015

Jacobsen, K. (2006). Refugees and asylum seekers in urban areas: a livelihoods perspective. Journal of Refugee Studies, 19(3), 273-286.

Johnston, V. (2009). Australian asylum policies: have they violated the right to health of asylum seekers? Australian \& New Zealand Journal of Public Health, 33(1), 40-6.

Kaldor Centre for International Refugee Law. (2013). Fact sheet: Enhanced screening process and fast track policies. University of New South Wales. http://www.kaldorcentre.unsw.edu.au/sites/kaldorcentre.unsw.edu.au/files/enhanced screenin g final 13.11.13.pdf. Accessed 2 August 2014.

Lundberg, P. (2013). Refugees' employment integration in Sweden: Cultural distance and labor market performance, Review of International Economics, 21, 219-232.

Marston, G. (2004). A punitive policy: labour force participation of refugees on temporary protection visas. Labour and Industry, 15 (1), 65-79.

McNevin, A. \& Correa-Velez, I. (2006). Asylum seekers living in the community on Bridging Visa E: community sector's response to detrimental policies. Australian Journal of Social Issues, 41(1), 125-139.

Melbourne Institute of Applied Economic and Social Research. (2013). Poverty Lines: Australia June Quarter 2013. 
http://melbourneinstitute.com/downloads/publications/Poverty\%20Lines/Poverty-linesAustralia-June2013.pdf. Accessed 24 August 2014.

Milosevic, D., Cheng, I. \& Smith, M. (2012). The NSW Refugee Health Service: improving refugee access to primary care. Australian Family Physician, 41(3), 147-9.

Morrison, S. (2013a). Minister for Immigration and Border Protection. Operation Sovereign Borders update'. 1 November. http://www.minister.immi.gov.au/media/sm/2013/sm209273.htm. Accessed 24 August 2014.

Morrison, S. (2013b). Minister for Immigration and Border Protection. Government implements behaviour code for illegal maritime arrivals in the community. 20 December. http://www.minister.immi.gov.au/search/cache.cgi?collection=immirss \&doc $=2013 \% 2 \mathrm{Fsm} 21$ 0412.xml. Accessed 24 August 2014.

Phillimore, J. \& Goodson, L. (2006). Problem or opportunity? Asylum seekers, refugees, employment and social exclusion in deprived urban areas. Urban Studies, 43, 1715-1736.

Phillips, J. \& Spinks, H. (2013). Boat Arrivals in Australia since 1976. http://www.aph.gov.au/About_Parliament/Parliamentary_Departments/Parliamentary_Librar y/pubs/rp/rp1314/BoatArrivals. Accessed 24 August 2014.

Refugee Council of Australia (2015). Migration and Maritime Powers Legislation Amendment (Resolving the Asylum Legacy Caseload) Act 2014: What it means for asylum seekers. $\quad$ http://www.refugeecouncil.org.au/wp-content/uploads/2015/02/1502-LegacyCaseload.pdf. Accessed 12 February 2015.

Silove, D. \& Steel, Z. (1998). The mental health and well-being of on-shore asylum seekers in Australia' Sydney: Psychiatry Research and Teaching Unit, School of Psychiatry, University of New South Wales.

Southern, W. (2013). Evidence to Senate Legal and Constitutional Committee, Parliament of Australia, Canberra, $\quad 19 \quad$ November. http://parlinfo.aph.gov.au/parlInfo/search/display/display.w3p; db=COMMITTEES;id=commi ttees\%2Festimate\%2F70373bf4-1745-474d-be50-

7e04b2a90004\%2F0001; query=Id\%3A\%22committees\%2Festimate $\% 2 F 70373$ bf4-1745-

474d-be50-7e04b2a90004\%2F0000\%22. Accessed 2 February 2015.

Spike, E.A., Smith, M.M. \& Harris, M.F. (2011). Access to primary health care services by community-based asylum seekers. Medical Journal of Australia, 195(4), 188-191.

Steel, Z., Momartin, S., Silove, D., Coello, M., Aroche, J. \& Tay, K.W. (2011). Two year psychosocial and mental health outcomes for refugees subjected to restrictive or supportive immigration policies. Social Science and Medicine, 72(7), 1149-56. 
Steel, Z., Silove, D., Brooks, R., Momartin, S., Alzuhairi, B. \& Susljik, I. (2006). Impact of immigration detention and temporary protection on the mental health of refugees. British Journal of Psychiatry, 188, 58-64.

Stupp, C. (2014). Germany struggles to house rising number of asylum seekers. IRIN, http://www.irinnews.org/report/100754/germany-struggles-to-house-rising-number-ofasylum-seekers. Accessed 17 May 2015.

Sulaiman-Hill, C.M.R. \& Thompson, S.C. (2012). Afghan and Kurdish refugees, 8-20 years after resettlement, still experience psychological distress and challenges to well being. Australian and New Zealand Journal of Public Health, 36(2), 126-134.

Taylor, S. (2000). Do on-shore asylum seekers have economic and social rights? Dealing with the moral contradiction of liberal democracy. Melbourne Journal of International Law, $1(1), 70-97$.

UNHCR. (2000). Reception Standards for Asylum Seekers in the European Union. http://www.unhcr.org/refworld/pdfid/3ae6b3440.pdf. Accessed 2 September 2013.

UNHCR. (2013a). War's Cost: UNHCR Global Trends 2013. http://www.unhcr.org/5399a14f9.html. Accessed 2 August 2014.

UNHCR. (2013b). Asylum-seekers on Bridging Visas in Australia: Protection Gaps. 16 December. $\quad$ http://unhcr.org.au/unhcr/images/2013-12-16\%20Asylumseekers\%20on\%20bridging\%20visas\%20in\%20Australia\%20-\%20.pdf. Accessed 2 February 2015.

Valenta, M. \& Thorshaug, K. (2012). Asylum-seekers' perspectives on work and proof of identity: The Norwegian experience, Refugee Survey Quarterly, 31, 76-97.

Waxman, P. (2001). The Economic Adjustment of Recently Arrived Bosnian, Afghan and Iraqi Refugees in Sydney, Australia. International Migration Review, 35(2), 472-505.

Wren, K. (2007). Supporting asylum seekers and refugees in Glasgow: the role of multiagency networks. Journal of Refugee Studies, 20(3), 391-413.

Yaxley, L., Norman, J. and Gul, J (2015). Temporary protection visas: Senate votes to bring back temporary visas after deal to get children off Christmas Island. $A B C$ News. 5 December. http://www.abc.net.au/news/2014-12-05/senate-agrees-to-reintroduce-temporary-protectionvisas/5945576. Accessed 12 February 2015. 